We thank Dr Ahmed Al-Ansari for endocrinological assessment.

\section{References}

${ }^{1}$ Shoval AR. Mixed gonadal dysgenesis. In: Rashad MN, Morton WRM, eds. Genital anomalies. Springfield, Illinois: Charles C Thomas, 1969:476-89.

2 Jones HWJ, Scott WW. Hermaphroditism, genital anomalies and related endocrine disorders. Baltimore: Williams \& Wilkins, 1971:290-317.

3 Davidoff F, Federman DD. Mixed gonadal dysgenesis. Pediatrics 1973;52:725-42.

4 Simpson JL. Disorders of sexual differentiation: etiology and clinical delineation. New York: Academic Press, 1976:237-9.

5 Al-Awadi SA, Cuschieri A, Farag TI, et al. Mixed gonadal dysgenesis and sex chromosome mosaicism with multiple cell lines including structural abnormalities of the $\mathrm{Y}$ chromosome. Clin Genet 1983;23:172-6.

${ }^{6}$ de la Chapelle A. Sex chromosome abnormalities. In: Emery $\mathrm{AEH}$, Rimoin DL, eds. Principles and practice of medical genetics. Edinburgh: Churchill Livingstone, 1983:193-215.

7 Al-Awadi SA, Farag TI, Naguib KK, et al. A five year experience with gonosomal abnormalities in Kuwait. $J$ Kwt Med Assoc 1984;18:225-32.

${ }^{8}$ Klebs E. Handbuch der Pathologischen Anatomise. Berlin: Hirchwals, 1876.

${ }^{9}$ Harnden DG, Armstrong CN. The chromosomes of a true hermaphrodite. $\mathrm{Br}$ Med J 1959;ii:1287.

${ }^{10}$ Hungerford DS, Donelley AJ, Nowell PC, Beck S. The chromosome constitution of a human phenotypic intersex. $\mathrm{Am}$ J Hum Genet 1959;2:215-36.

" Gartler SM, Waxman SH, Giblett E. An XX/XY human hermaphrodite resulting from double fertilization. Proc Natl Acad Sci USA 1962;48:332-5.

12 Van Niekerk WA. True hermaphroditism. New York: Harper, 1974.

${ }^{13}$ Manuel MA, Allie A, Jackson WPU. A true hermaphrodite with $\mathrm{XX} / \mathrm{XY}$ chromosome mosaicism. $S$ Afr Med J 1965;39:414-9.

14 Massimo L, Vianello MG. Chromosome studies in two cases of intersexuality. Human Chromosome Newsletter 1965;15:15-16.

15 Race RR, Sanger R. Blood groups in man. 6th ed. Oxford: Blackwell, 1975:531-9.

16 Fitzgerald PH, Brehaut LA, Shannan FT, Angus HE. Evidence of $\mathrm{XX} / \mathrm{XY}$ sex chromosome mosaicism in a child with true hermaphroditism. J Med Genet 1970;7:383-8.

17 Park IJ, Jones HW Jr, Bias WG. True hermaphroditism with ambiguous external genitalia. Am J Obstet Gynecol 1970;108:1197-205.

${ }^{18}$ Kakati S, Sharma T, Udupa KN, Chaudhuri SPR. A true hermaphrodite with $\mathrm{XX} / \mathrm{XY}$ mosaicism. Ind $\mathrm{J}$ Med Res 1971;59:104-6.

19 Benirschke K, Naftalin F, Gittes R, Khuder G, Yen SSC, Allen FH. True hermaphroditism and chimerism. Am J Obstet Gynecol 1972;113:449-58.

${ }^{20}$ Grace JH. A white hermaphrodite in South Africa. $S$ Afr Med J 1973;47:1553-4

21 Shanfield I, Young RB, Hume DM. True hermaphroditism with $\mathrm{XX} / \mathrm{XY}$ mosaicism: report of a case. $J$ Pediatr 1973;83:471-3.

22 de la Chapelle A, Schröder J, Rantanen P, et al. Early fusion of two human embryos. Ann Hum Genet 1974;38:63-75.

23 De Marchi M, Carbonara AO, Carozzi $\mathrm{F}$, et al. True hermaphroditism with XX/XY chromosome mosaicism: report of a case. Clin Genet 1976;10:265-72.

${ }^{24}$ Fitzgerald PH, Donald RA, Kirk RL. A true hermaphrodite dispermic chimera with 46,XX and 46,XY karyotypes. Clin Genet 1979;15:89-96.

25 Dewald G, Haymond MW, Spurbeck JL. Origin of $46, \mathrm{XX}$ $46, \mathrm{XY}$ chimerism in a human true hermaphrodite. Science 1980;207:321-3.

${ }^{26}$ Shah VC, Krishna Murthy DS, Sabita Roy, Contractor PM, Shah VA. True hermaphrodite $46, \mathrm{XX} / 46, \mathrm{XY}$ : clinical, cytogenetic and histopathological studies. Ind $J$ Pediatr 1982;49:885-90.

27 Borgoankar DS. Chromosomal variation in man. A catalog of $\overrightarrow{0}$ chromosomal variants and anomalies. 3rd ed. New York: Also R Liss, 1980:483-5.

28 de Grouchy J, Turleau C. Clinical atlas of human chromes. somes. 2nd ed. New York: John Wiley, 1984:406-8.

${ }^{29}$ Schinzel A. Catalogue of unbalanced chromosome aberration in man. Berlin: Walter de Gruyter, 1984:812-3.

31) Tippett P. Human chimeras. In: Chimeras in developmental biology. London: Academic Press, 1984:165-78.

31 Ford CE. Mosaicism and chimeras. Br Med Bull 1969;25:104-9.

Correspondence and requests for reprints to $\mathrm{Dr}$ Patricia Tippett, MRC Blood Group Unit, Wolfson House, University College London, 4 Stephenson Way, London NW1 2HE.

\title{
Interstitial del(13)(q21.3q31) associated with psychomotor retardation, eczema, and absent suck and swallowing reflex
}

\section{P J PEET, R RODRIGUES PEREIRA, J O VAN HEMEL, AND}

A J M HOOGEBOOM

Department of Paediatrics, St Clara Hospital, and Department of Clinical Genetics, Erasmus University, Rotterdam, The Netherlands.

SUMMARY A patient with a deletion (13)(q21.3q31) showed only eczema and ab-

Received for publication 24 November 1986. Accepted for publication 28 November 1986 sent suck and swallowing reflex, in contrast to other well documented cases with a similar deletion. Apparently there is wide clinical? variability in patients with deletions in this area. 
Cases with partial deletions of the long arm of chromosome 13 constitute a clinically and cytogenetically heterogeneous group. We describe a patient with a del(13)(q21.3q31) and compare our findings with well documented cases of deletions in the same region.

\section{Case report}

The proband, a boy, was the fourth child of healthy, unrelated parents. After an uneventful pregnancy the infant was born at term weighing $2635 \mathrm{~g}$. In the neonatal period he was observed in another hospital for one week for possible sepsis. Three months later he was admitted because of failure to thrive and feeding difficulties.

He was a small boy (weight $3720 \mathrm{~g}$, length $54 \mathrm{~cm}$, head circumference $37 \mathrm{~cm}$ ) with extensive eczema (fig 1). Retardation of psychomotor development, muscular hypotonia, weak tendon reflexes, absent suck and swallowing reflex, and inability to follow with the eyes were present. He had a partly depigmented right iris and low set, normal ears. No cardiac murmur was audible. There were recurrent

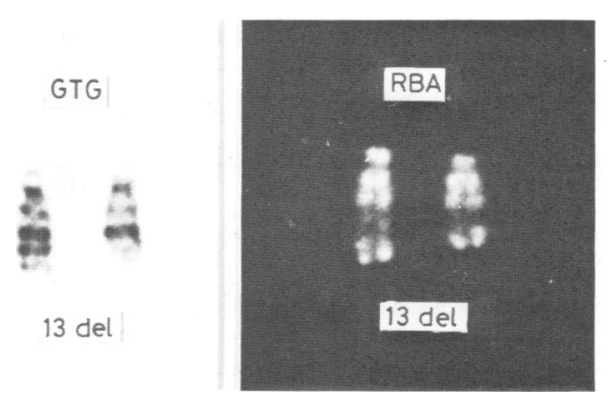

FIG 2 GTG and RBA banded chromosome 13.

respiratory and urinary tract infections. Radiography revealed no urinary tract anomalies. A CT scan of the brain was normal.

\section{CYTOGENETIC STUDIES}

GTG and RBA banded chromosomes from blood lymphocytes and skin fibroblasts showed a 46,XY, del(13)(pter $\rightarrow$ q21·3::q31 $\rightarrow$ qter) karyotype in all metaphases analysed (fig 2).

Both parents had normal chromosomes.

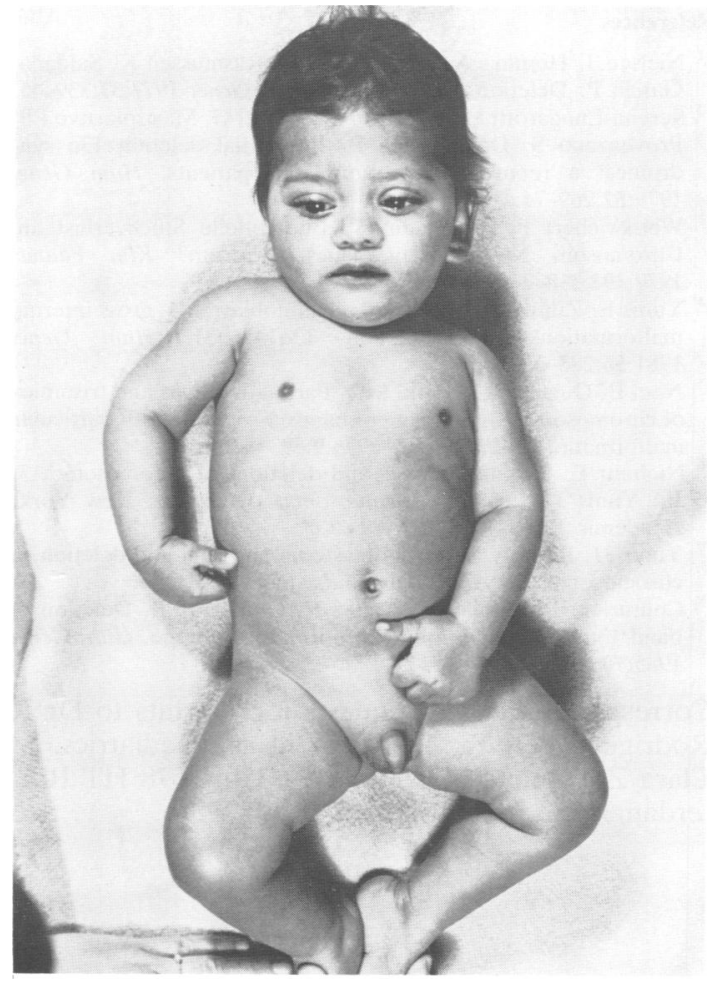

FIG 1 The proband at five months.

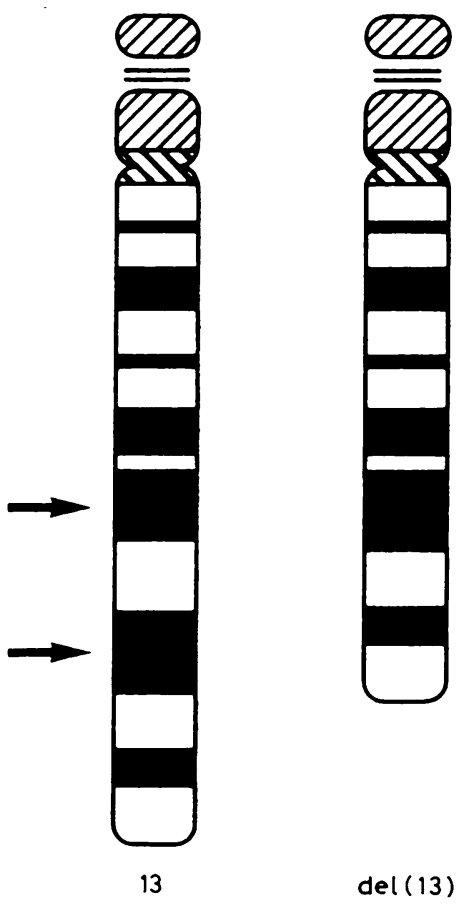

FIG 3 Schematic diagram of $\operatorname{del}(13)(q 21 \cdot 3 q 31)$. 
TABLE Clinical and cytogenetic features in $13 q$ monosomy.

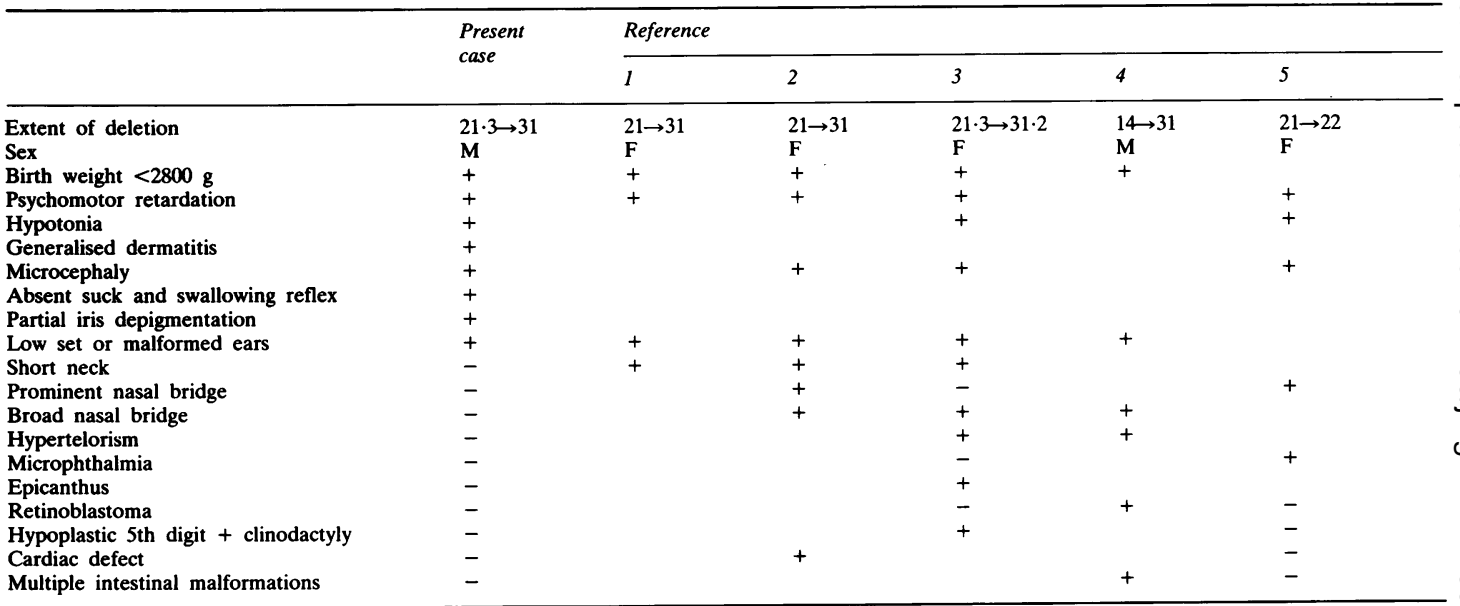

\section{Discussion}

Clinical symptoms associated with $13 q$ deletions are variable. Comparison of cases with deletions in the same region as our patient (table) $)^{1-5}$ does not help to establish a definite clinical pattern ${ }^{6}$; psychomotor retardation seems to be the most constant finding.

Gross intestinal malformations are possibly associated with deletions in the region $\mathrm{q} 13 \rightarrow \mathrm{q} 31,47$ and deletion of band $13 \mathrm{q} 14$ is associated with retinoblastoma. ${ }^{7}$ Our case shows absence of suck and swallowing reflexes which has not previously been reported, and extensive eczema; dermatitis has been reported in one other case.

More distal deletions may give a recognisable clinical picture. Deletion of band 13q34 is probably responsible for the craniofacial dysmorphism classically described in the $13 \mathrm{q}$ monosomy syndrome. ${ }^{6}$ Thumb hypoplasia is variably present in deletion $13 q 34 .^{6}$ The wide phenotypical variability is also demonstrated by the normal phenotype in a case with a deletion of band $13 \mathrm{q} 21 .{ }^{8}$ This was explained by the fact that this band is one of the latest replicating, which may indicate that it carries genetic material which is not transcriptionally active.

Establishing a definite phenotype for deletions in this region, if at all possible, will certainly require more cases studied by high resolution banding techniques.
The authors would like to thank Professor M F Niermeijer for his critical comments and helpful suggestions.

\section{References}

${ }^{1}$ Nielsen J, Homma A, Christiansen F, Rasmussen K, Saldaña Garcia P. Deletion long arm 13. Hum Genet 1977;37:339-45.

2 Serena-Lungarotti M, Calabro A, Mariotti G, Mastroiacovo P $\mathrm{P}$ Provenzano S, Dallapiccola B. Interstitial deletion 13q syndromes: a report on two unrelated patients. Hum Genet 1979;52:269-74.

3 Weisswichert $P$, Stögmann W. Interstitielle Stückverlust am Chromosom Nr 13: Ein neues Syndrom? Klin Pädiatr 1979;191:318-24.

4 Yunis E, Zuñiga R, Ramírez E. Retinoblastoma, gross internal malformations and deletion $13 \mathrm{q} 14 \rightarrow \mathrm{q} 31$. Hum Genet $1981 ; 56: 283-6$.

5 Noel B, Quack B, Rethoré MO. Partial deletions and trisomies of chromosome 13: mapping of bands associated with particular malformations. Clin Genet 1976;9:593-602.

6 Niebuhr E. Partial trisomies and deletions of chromosome 13. In: Yunis JJ, ed. New chromosomal syndromes. New York: Academic Press, 1977:273-99.

7 Yunis JJ, Ramsay N. Retinoblastoma and subband deletion of chromosome 13. Am J Dis Child 1978;132:161-3.

8 Couturier J, Morichon-Delvallez N, Dutrillaux B. Deletion of band $13 \mathrm{q} 21$ is compatible with normal phenotype. Hum Genet 1985;70:87-91.

Correspondence and requests for reprints to $\mathrm{Dr} R$ Rodrigues Pereira, Department of Paediatrics, St N Clara Ziekenhuis, Olympiaweg 350, 3078 HT Rotterdam, The Netherlands. 